\title{
Linking better shiftwork arrangements with safety and health management systems
}

\author{
Kazutaka Kogi \\ Institute for Science of Labour. Kawasaki, Japan
}

\section{Keywords}

Shift work. Night work. Working conditions. Occupational safety and health management systems.

Ergonomics (environmental health) Risk assessment.

\section{Descritores}

Trabalho em turnos. Trabalho noturno. Condições de trabalho. Saúde ocupacional. Medidas de segurança. Ergonomia (saúde ambiental). Medição de risco.

\begin{abstract}
Objectives

Various support measures useful for promoting joint change approaches to the improvement of both shiftworking arrangements and safety and health management systems were reviewed. A particular focus was placed on enterprise-level risk reduction measures linking working hours and management systems.

Methods

Voluntary industry-based guidelines on night and shift work for department stores and the chemical, automobile and electrical equipment industries were examined. Survey results that had led to the compilation of practicable measures to be included in these guidelines were also examined. The common support measures were then compared with ergonomic checkpoints for plant maintenance work involving irregular nightshifts. On the basis of this analysis, a new night and shift work checklist was designed.

Results

Both the guidelines and the plant maintenance work checkpoints were found to commonly cover multiple issues including work schedules and various job-related risks. This close link between shiftwork arrangements and risk management was important as shiftworkers in these industries considered teamwork and welfare services to be essential for managing risks associated with night and shift work. Four areas found suitable for participatory improvement by managers and workers were work schedules, ergonomic work tasks, work environment and training. The checklist designed to facilitate participatory change processes covered all these areas.

Conclusions

The checklist developed to describe feasible workplace actions was suitable for integration with comprehensive safety and health management systems and offered valuable opportunities for improving working time arrangements and job content together.
\end{abstract}

\section{Resumo}

Objetivos

Foram revisados diversas medidas de apoio úteis para incentivar abordagens conjuntas para a melhoria na organização do trabalho por turnos e os processos de gestão de saúde e segurança. As medidas para redução de risco em nível empresarial que associam horas de trabalho e processos de gestão receberam um enfoque particular.

Presented at the XVI International Symposium on Night and Shiftwork, N ovember 2003. Santos, SP, Brazil. Received on 15/3/2004. Approved on 27/9/2004
Correspondence to:

Kazutaka Kogi

Institute for Science of Labour

2-8-14, Sugao, Miyamae-ku, Kawasaki 216-

8501, Japan

E-mail: k.kogi@isl.or.jp 


\begin{abstract}
Métodos
Foram analisadas as diretrizes voluntárias do setor para o trabalho noturno e em turnos em lojas de departamento e indústria química, automobilística e de equipamentos elétricos. Também foram examinados os resultados das pesquisas que levaram à formulação de medidas viáveis a serem incluídas nestas diretrizes. Em seguida, as medidas regulares de apoio foram comparadas com pontos de controle ergonômico para o trabalho de manutenção das instalações que requer turnos noturnos irregulares. Com base na análise foi criada uma lista de verificação para o trabalho noturno e em turnos.

Resultados

Verificou-se que tanto as diretrizes quanto os pontos de controle do trabalho de manutenção das instalações cobriram freqüentemente vários assuntos, inclusive horários de trabalho e riscos relativos ao trabalho. Este vínculo próximo entre a disposição do trabalho em turnos e a gestão de risco revelou-se importante, visto que os trabalhadores em turnos nestes ramos consideraram o trabalho em equipe e em serviços de previdência essenciais para a gestão de riscos associados ao trabalho noturno e em turnos. As quatro áreas identificadas pelos administradores e empregados próprias para a melhoria participativa foram: horários de trabalho, tarefas ergonômicas, ambiente de trabalho e treinamento. A lista de verificação elaborada para facilitar os processos de reforma participativa cobria estas áreas. Conclusões

A lista de verificação elaborada para descrever medidas viáveis para o local de trabalho serviu para a integração com os processos abrangentes de gestão de saúde e segurança e proporcionou oportunidades importantes para a melhoria conjunta da disposição das horas de trabalho e teor do trabalho.
\end{abstract}

\section{INTRODUCTION}

In improving conditions of shiftwork in industry, there is a clear trend toward joint change approaches to improving both work schedules and safety and health management. This is because awareness is growing that safer and healthier shiftwork conditions require not only better working time arrangements but also appropriate management of multiple workplace risks. ${ }^{6,12,18,19}$

The need to address various job-related factors has been stressed since the early discussions of shiftwork interventions. Rutenfranz $z^{17}$ (1982), for example, emphasized the need to take into account various jobrelated intervening variables in reducing strains due to night and shift work. The spread of flexible work schedules has also drawn attention to the combined effects of working time arrangements and other aspects of workplace conditions. , $^{2,814}$ International standards and various guidelines about night work and shift systems have incorporated both working time arrangements and health-related measures. ${ }^{1,5,10}$

The recent development of occupational safety and health management systems has facilitated joint change approaches to improving work schedules and other workplace conditions together. ${ }^{4,9,15}$ Often, improved working schedules are addressed as an essential element of safety and health management systems organized as part of business management. Thus, usu- ally when line managers and workers take steps in managing workplace risks, long hours of work and irregular work schedules are simultaneously assessed. It is therefore important to provide support for assessing multiple job-related factors in close association with shiftwork conditions. ${ }^{6,7}$ There are many ergonomic and environmental aspects that are particularly relevant in working irregular shifts. Recent experiences in improving conditions of shiftworkers show that assessment tools addressing these various aspects are very helpful in implementing improvements in both work schedules and other workplace conditions. ${ }^{11,18}$

In this paper, recent voluntary guidelines on night and shift work and enterprise-level intervention projects were reviewed to know the types of support useful for the joint change of work schedules and other workplace conditions. Based on these experiences, the coverage of assessment items useful for such support was examined. As a result, a new night and shift work checklist was designed. The checklist is presented for its use in industrial workplaces.

\section{METHODS}

Recent industry-based voluntary guidelines on night and shift work issued by several industries in Japan were reviewed. These guidelines were compiled by advisory groups based on surveys of measures taken by enterprises and those by workers, as dis- 
cussed by Sakai et $\mathrm{al}^{18}$ (2000). These groups were usually formed by representatives of managers and workers with the support of shiftwork experts. The guidelines reviewed included those compiled by the corresponding groups of the chemical industry in 2000 , the automobile and parts industry in 2000, the electrical equipment industry in 2001 and the department stores in 2002.

The results of the surveys referred to by these groups were examined. The surveys involved 92 enterprises in the chemical industry, 47 enterprises in the automobile industry, 113 enterprises in the electrical equipment industry and 104 department stores. The surveyed enterprises were those members of each industry-based association that replied to a questionnaire about shitworking conditions and relevant support measures. The rates of enterprises improving working time measures and those of enterprises improving other support measures for shiftworkers were examined.

These support measures were compared with the ergonomic checkpoints used in shiftwork interventions in power plant maintenance work. ${ }^{11}$ Each checkpoint consisted of information about how to improve a particular aspect of shiftworking conditions, such as reducing night work frequencies or providing adequate sleeping facilities. These checkpoints had been developed based on a field study of night work conditions. They comprised 42 checkpoints covering workplace conditions, work schedules and working life conditions.

These checkpoints were further examined by a study group in the Institute for Science of Labour engaged in shiftwork research. As a result, a 48-item action checklist for assessing night and shiftwork conditions was designed incorporating items related to work schedules and other workplace conditions. The application of such an action checklist to participatory joint change approaches was discussed.

\section{RESU LTSAND DISCUSSION}

\section{Voluntary industry-based guidelines for improving shiftwork}

It was noteworthy that all the voluntary industrial guidelines reviewed had been prepared by examining support measures commonly applicable to the various shiftwork systems in the corresponding industries. The surveys conducted in these industries revealed diversified shift systems to meet the market demands. In the chemical industry, the shift systems applied by the 92 enterprises included twoteam two-shift systems (for $1 \%$ of shiftworkers), fourteam two-shift systems (for 7\%), three-team three-shift systems (for 4\%), four-team three-shift systems (for $60 \%$ ), five-team three-shift systems (for 17\%), 9-team three-shift systems (for 1\%) and other systems (for $10 \%$ ). In the electrical equipment industry, the shift systems applied by the 113 enterprises included twoor three-team two-shift systems (for $25 \%$ of shift workers), four-team two-shift systems (for 18\%), three-team three-shift systems (for 20\%), four-team three-shift systems (for $23 \%$ ), five-team three-shift systems (for $7 \%$ ) and other systems (for 7\%). This diversity was equally seen in other industries. In department stores, many irregular shift systems were used to cover night work in security and maintenance, sales, marketing and information services.

The survey results referred to in these guidelines are shown in Figure 1. A variety of measures were taken by the surveyed enterprises concerning work schedules as well as teamwork arrangements and welfare facilities for shiftworkers.

In addition to improved work schedules, efforts were made variously by these enterprises in limiting night workload, reducing auxiliary tasks at night, transferring to day work for reasons of family responsibilities and health reasons, avoiding isolated work and assigning relief personnel in absences due to family reasons. Further, various measures were also taken as to welfare facilities and services for shiftworkers.

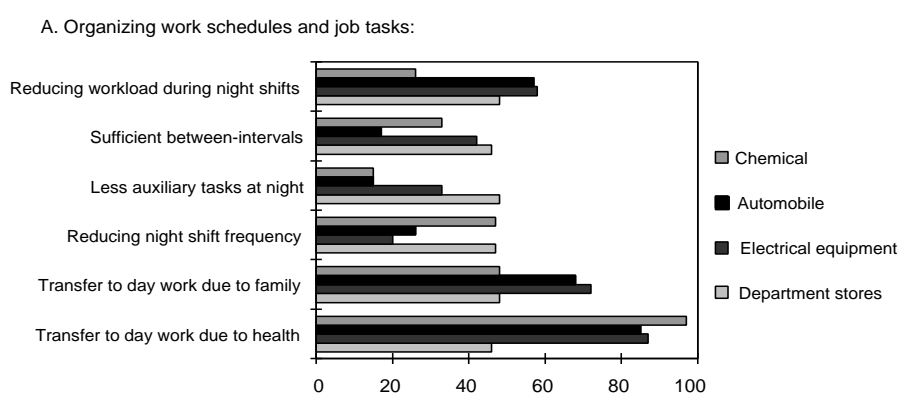

B. Conditions of teamwork and welfare facilities and services:

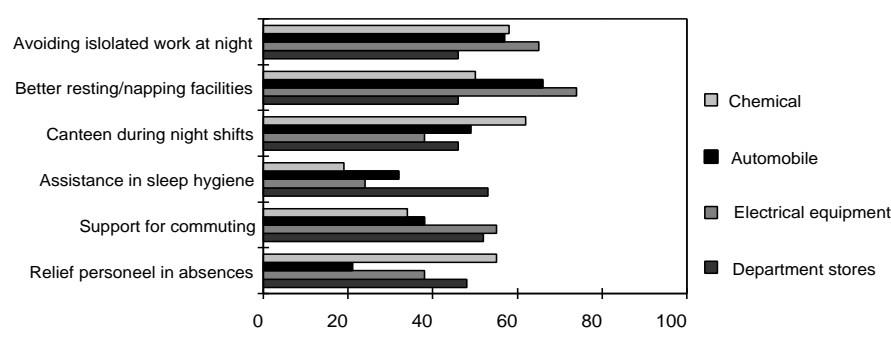

Figure 1 - Percentages of enterprises taking different support measures for night workers in the chemical, automobile and electrical equipment industries and department stores. 
The differences between industries were tested according to the chi-square tests conducted for each of these items. The results were significant at 0.01 level for all the items in Figure 1, except "avoiding isolated work at night" that had similar rates for the four industries. These differences were apparently related to the ways the shift systems were organized. Reducing workload and auxiliary tasks during nightshifts and securing sufficient between-shift intervals were more frequently mentioned in the electrical equipment industry and department stores, whereas canteen services were less frequently applied there. Such differences were related to the fact that the work in different shifts was more stably organized in the chemical and automobile industries. On the other hand, the transfer to day work for health reasons was adopted by most enterprises in the chemical, automobile and electrical equipment industries. It was noteworthy that many enterprises were applying multiple measures in work organization, welfare facilities and other support measures.

The advisory groups organized to prepare the voluntary guidelines in these industries noted this clear trend towards taking a variety of support measures for improving various shift systems. Thus, these groups compiled the voluntary guidelines with a view to improving shiftwork in both work schedules and other multiple conditions. The guidelines were published in a serial manner; in the chemical industry and the automobile industry in 2000, the electrical equipment industry and the iron and steel industry in 2001 and the department stores in 2002. Similar attempts were undertaken in other industries and health care institutions.

The wide coverage of required support measures was common to all these industry-based guidelines. Usually these support measures corresponded to improvements in work schedules, work tasks, resting and health measures and training. This was because all the advisory groups carefully examined the international standards, governmental guidance and recent recommendations by shiftwork experts. About work schedules, commonly mentioned measures were securing betweenshift intervals, keeping regular shift cycles, avoiding excessive overtime and securing relief personnel for absences. About work tasks, the measures mentioned included reducing workload during night shifts, assigning less auxiliary tasks at night shifts, avoiding isolated work at night and improved working environment. As for resting and health measures, all the four guidelines mentioned improved resting and napping facilities, assistance in sleep and commuting, strengthening health counseling and transfer to day work due to health or family reasons. About training, training for coping with work stress was mentioned by all the guidelines, whereas better communication in emergency was mentioned in those for the automobile and electrical equipment industries and department stores and opportunities for career training by those for the electrical equipment industry. It could be confirmed that the need for joint change approaches were generally recognized through these guidelines.

\section{Linking shiftwork checkpoints with risk management}

Similar attempts to cover both work schedules and ergonomic and other workplace conditions within the scope of such joint change approaches were examined. One typical example was the checkpoints for assessing conditions of shiftwork for plant maintenance..$^{11,12}$ The checkpoints, or a set of measures to be checked about their applicability in improving existing conditions, had been compiled based on the field study of plant maintenance work. They were found useful for training managers and workers.

The broad scope of the checkpoints was particularly useful for plant maintenance work. The shift systems for this mainly subcontracted workforce were characterized by irregular work schedules combined with weekly rotated twelve-hour shifts. The difficulties met during night shifts by maintenance workers mainly related to long hours of work, frequent changes of work tasks, deadlines for completing variously assigned tasks, problems in teamwork communication, narrow work space, poor working environment associated with high temperatures, insufficient lighting and noise in some work areas and poor resting conditions. Accordingly, the four main areas selected for the checkpoints, including night work tasks, work schedules, support for resting and health control and training, covered these aspects.

When these checkpoints were compiled, a special emphasis was placed on selecting those measures for which feasible options of reducing work-related risks could be presented. As occupational safety and health management systems spread to the plant level, such measures were found to closely relate to effective risk management. It was therefore considered appropriate to incorporate these points within the risk management process.

The four areas of the checkpoints for assessing plant maintenance work were thus found suitable for the joint change of work schedules and safety and health risk reduction. Table summarizes this link between the selected measures for improving shiftwork conditions and risk management. 
Table - The link between the measures selected as shiftwork checkpoints and risk reduction in plant maintenance work.

\begin{tabular}{llll}
\hline Area & Problems met in plant work & Main checkpoints & Risk reduction \\
\hline Work schedules & Irregular twelve-hour shifts & Annual planning & Better rotation \\
& Uncoordinated night duties & Reorganizing night duties & Less-risk tasks \\
Work tasks & Excessive, unsafe work load & Ergonomic worksite & Safer practices \\
& Improved working environment & Lighting/screened hazard & Efficient work \\
& Isolated work at night & Avoiding isolation & Mutual help \\
Resting/health & Poor communication & Communication aids & Avoiding risks \\
& Lack of adequate rest & Rest/sleeping facilities & Less fatigue \\
& Lack of health counseling & Health/diet counseling & Early findings \\
Training & Lack of freetime support & Freetime/commuting aids & Less conflicts \\
& Unsystematic training & Safety/coping training & Self-check \\
& Poor career building & Upgrading work skills & Teamwork \\
\hline
\end{tabular}

One should note that the range of these measures was strikingly similar to that of measures used in workplace interventions in different settings. ${ }^{3,13}$ As in the case of workplace interventions applying participatory approaches such as Work Improvement in Small Enterprises (WISE) methodology developed by the ILO, the shiftwork checkpoints also highlighted practicable options for improving existing conditions. As a rule, materials handling, workload, work environment and welfare facilities and services were similarly covered. All these multiple areas were incorporated also in the measures suitable for plant maintenance work. Further, the focus was always on feasible options with respect to both work schedules and other workplace conditions. For example, the checkpoint about napping also focused on possible options, such as different napping periods of 1-2 hours taken up to 4 a.m. and separate napping facilities adjusted to each local situation. The set of measures covering multiple areas could thus be useful for identifying practicable interventions not only for improving conditions of work in general but for keeping alertness, reducing workload and potential errors and adjusting to phase-shifted circadian rhythms.

\section{Designing an action checklist for improving night and shift work}

These experiences indicated that joint change approaches with a broad scope for assessing job-related factors were essential in developing useful checkpoints. ${ }^{14,18,19}$ This was in accordance with the general procedures of safety and health risk management, ${ }^{13}$ where multifaceted check procedures and participatory planning of prioritized preventive measures should be followed. ${ }^{3,12,16}$ It is of interest that similar participatory steps have been likewise taken in most experiences of improving shiftwork conditions in multiple aspects.

This similarity of shiftwork interventions addressing multiple job-related conditions with participatory risk management seems important. As provided in the ILO's Occupational Safety and Health Management Systems Guidelines (ILO-OSH 2001) and other generally applicable guidelines, the risk management process may follow the essential steps of (a) planning of the risk assessment and control process, (b) checking feasible actions, (c) obtaining feedback from local people to implement prioritized actions and (d) review for continual improvement action. ${ }^{4}$ This "Plan-Do-Checkand-Act" process has proven effective in risk assessment and control in different industries. A similar process was seen to be followed in shiftwork interventions. The process could be done systematically by taking participatory steps that included planning and implementation of practical measures as well as checking multiple aspects of remaining safety and health risks.

The examples of participatory steps taken in either of safety and health risk management and shiftwork interventions are shown in Figure 2.

Based on these experiences, a new checklist listing practicable actions was designed. This "Night and Shift Work Checklist" listed 48 items covering major areas useful for assessing shiftwork conditions with a view to taking a joint change approach. These items are shown in the Appendix at the end of this paper. A major emphasis of the checklist was placed on pre- (a) Developing shiftwork guidelines

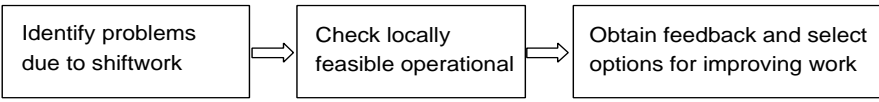

(b) Improving conditions of shiftwork

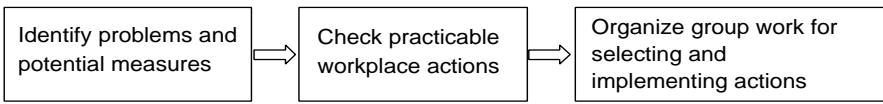

(c) Managing multiple safety and health risks

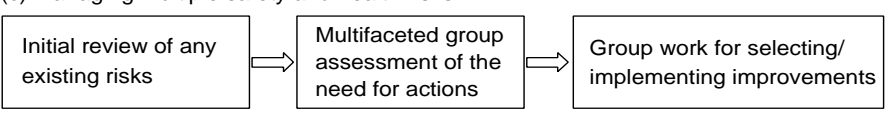

Figure 2 - Common participatory steps for developing and using nigh and shift work checkpoints in comparison with occupational safety and health management steps. 
senting practicable options and covering various aspects of workplace actions that could contribute to safer and healthier conditions of work. Each item was to indicate a potential action that could be taken in improving the existing conditions of shiftwork. Thus, the checklist included actions in (1) safe and ergonomic work tasks (17 items), (2) better working time arrangements (10 items), (c) support for resting and health promotion (15 items) and (d) lifecycle development and safety culture (6 items). A number of workplace actions for improving ergonomic aspects of work task assignments and work environment were included in addition to those concerning work schedules and resting conditions.

The combination of these four categories of check items in the checklist was considered essential. Since the checklist was designed for workplace-level group work, the inclusion of items related to night work and environmental conditions could obviously facilitate group assessment of workplace conditions. It was considered useful to design the checklist so as to consist of locally applicable measures. The users of the checklist, in particular managers and workers, could agree on some measures while paying attention to the overall work redesign in its multiple aspects.

The proposed structure of the new checklist is therefore beneficial for associating the improvement of night and shift work conditions with the overall safety and health management actions. Firstly, many of the items in the new checklist may be incorporated in the risk assessment steps. Secondly, the focus on readily practicable improvement actions may facilitate the joint action of managers and workers. Thirdly, the action forms of the check items are suitable for using the check items in participatory steps for dealing with existing problems in multiple workplace aspects.

In participatory workplace improvement projects involving shiftwork systems, support was usually given in order to jointly change both working time arrangements and workplace conditions. This was clearly reflected in the industry-based guidelines on shiftwork recently developed in several industries. These guidelines were in accordance with the checkpoints compiled for improving conditions of shiftwork in plant maintenance work. The participatory steps in making such changes could be taken as part of occupational safety and health management systems. These experiences clearly pointed to the importance of using appropriate group work tools for identifying practicable solutions in multiple areas. To facilitate the use of group work in shiftwork interventions, a new 48-item action-oriented checklist was developed that took into account the need for improving these multiple areas.

The composition of the proposed checklist covered many of the areas included in the Guidelines for Shiftworkers by Wedderburn. ${ }^{19}$ The number of the items in the new checklist was less than that in this previous guidelines because the checklist was considered for direct use of managers and workers in conducting group work for identifying potential options. While the checklist included main items to be considered in improving shiftwork systems, as suggested by Knauth, ${ }^{5}$ Monk et $\mathrm{al}^{15}$ and others referring to shiftworking arrangements, it also contained those items considered essential for improving ergonomic conditions of work, resting facilities and training opportunities. ${ }^{11}$ In so doing, the checklist took advantage of the action form of checklist items as advocated in similarly action-oriented checklists for multiple improvements of workplace conditions. ${ }^{4}$ This form of checklist items was found suitable for promoting participatory steps of managers and workers in improving shiftworking conditions. ${ }^{11,14}$ Thus, the "Night and Shift Work Checklist" may be used for organizing group work for assessing job-related risks and work schedules. The checklist will be particularly applicable to supporting participatory steps in which managers and workers jointly examine the conditions of night and shift work as part of safety and health management.

\section{APPENDIX}

\section{Night and Shift Work Checklist.}

\section{How to use the checklist}

1. Define the group of night and shift workers whose working conditions are examined.

2. Obtain information about basic shift schedules and working hours.

3. Spend some minutes walking around the work area of the selected group of workers.

4. For each item, select NO or YES: If the action has already been applied or it is not needed, select NO; or alternatively, if you propose the action, select YES.

5. Put down your suggestions or good examples.

6. Choose a few urgent items requiring immediate action, and tick PRIORITY for these items.

7. Organize group work to discuss existing good points and necessary improvements. 
1. Transfer to daytime some of the tasks that can be more dangerous during night shifts.

2. Use safer, less strenuous work methods particularly for night shifts.

3. Strengthen measures limiting the effects of human errors.

4. Make sure that safe work procedures are observed properly in carrying out hazardous work tasks particularly during night shifts.

5 . Agree on and apply good teamwork procedures appropriate for both daytime and night work.

6 . Avoid isolated tasks done during night shifts.

7. Improve ventilation and install air-conditioning to enhance thermal comfort in all shifts.

8. Secure adequate lighting for all tasks including those done only occasionally at night

9. Isolate or screen sources of work-disturbing noise.

10. Keep passageways and access routes cleared from obstacles at all times by organizing materials

and tools storage properly.

11. Work at elbow height in natural postures avoiding bending, twisting or arm-raising postures as much as possible.

12. Use hand-trucks, lifting devices or other mechanical means for moving heavy or frequently handled materials.

13 Make signals, displays or instructions easy to identify at all times, using for example colour coding.

14. Establish time-frame and procedures of transmitting verbally and in writing safety-related and other essential information to the crew of the next shift.

15. Promote good communication between workers and between managers and workers.

16. Establish emergency communication procedures, such as first aid and fire-fighting, and keep them posted at all times.

17. Designate key persons responsible for managing safety and health risks on a continual basis including all shifts.

[ ] No [ ] Yes [ ] Priority
$[$ ] No[ ] Yes [ ] Priority
[ ] No[ ] Yes [ ] Priority

[ ] No [ ] Yes [ ] Priority
[ ] No [ ] Yes [ ] Priority
[ ] No [ ] Yes [ ] Priority
[ ] No [ ] Yes [ ] Priority
[ ] No [ ] Yes [ ] Priority
[ ] No [ ] Yes [ ] Priority
[ ] No [ ] Yes [ ] Priority

[ ] No [ ] Yes [ ] Priority

[ ] No [ ] Yes [ ] Priority

[ ] No [ ] Yes [ ] Priority

[ ] No [ ] Yes [ ] Priority [ ] No [ ] Yes [ ] Priority

[ ] No [ ] Yes [ ] Priority

[ ] No [ ] Yes [ ] Priority

\section{Better Working Time Arrangements}

18. Make specific plans for working hours per day, week, month or year

19. Fix shift lengths adequate for task loads (for example, long shifts only for non-strenuous,

[ ] No [ ] Yes [ ] Priority relatively intermittent work).

20. Avoid short intervals of time off between two shifts, such as 8 or 10 hours only.

21. Plan days off at adequate intervals.

22. Make some weekends free.

23. Keep rotas regular.

24. Make plans for substituting absent workers in advance.

25. Minimize the number of consecutive night shifts.

26. Allow some individual flexibility in working different shifts.

27. Make an annual plan for coordinating frequencies of night shifts, daytime shifts, days off and leave periods.

[ ] No [ ] Yes [ ] Priority
[ ] No [ ] Yes [ ] Priority
[ ] No [ ] Yes [ ] Priority
[ ] No [ ] Yes [ ] Priority
[ ] No [ ] Yes [ ] Priority
[ ] No [ ] Yes [ ] Priority
[ ] No [ ] Yes [ ] Priority
[ ] No [ ] Yes [ ] Priority

[ ] No [ ] Yes [ ] Priority

III. Support for Resting and Health Promotion

28. Insert breaks of adequate length during each shift including a night shift

29. Allow a napping period of adequate length during a night shift depending on the needs and preferences of workers

30. Provide comfortable and hygienic facilities for resting and, where appropriate, for napping.

31. Provide, where appropriate, sleeping facilities that are air-conditioned and undisturbed by environmental noise.

32. Provide information and training about planning adequate sleep time-tables and reducing sleep disturbances.

33. Give concrete support for improving sleep environment at workers' residence.

34. Provide information about taking meals appropriately also taking individual workers' habits into account.

35. Provide information and necessary supporting facilities for getting nutritious meals suitable

for all shifts including night shifts.

36. Provide information and arrange for supporting facilities for keeping physical fitness

37. O rganize educational sessions for workers about self-check of their health and improving

their coping behaviour.

38. Provide counseling services by occupational physicians, occupational health nurses,

nutritionists or psychologists about maintaining and promoting the health of workers.

39. Monitor at regular intervals the physical and mental health problems of night and shift

workers and use the results for taking appropriate workplace action.

40. Provide support for transport facilities particularly before and after night shifts.

41. Encourage workers to share household duties and make time-spaces to be with and to eat with their spouses and children.

42. Encourage and support workers to plan free-time activities positively.

[ ] No [ ] Yes [ ] Priority

[ ] No [ ] Yes [ ] Priority

[ ] No [ ] Yes [ ] Priority

[ ] No [ ] Yes [ ] Priority

[ ] No [ ] Yes [ ] Priority [ ] No [ ] Yes [ ] Priority

[ ] No [ ] Yes [ ] Priority

[ ] No [ ] Yes [ ] Priority [ ] No [ ] Yes [ ] Priority

[ ] No [ ] Yes [ ] Priority

[ ] No [ ] Yes [ ] Priority

[ ] No [ ] Yes [ ] Priority

] No [ ] Yes [ ] Priority [ ] No [ ] Yes [ ] Priority

\section{Lifecycle Development and Safety Culture}

43. Conduct educational programmes for all new night and shift workers about how to deal with irregular shifts and about improving safety at work. 44. O rganize group training workshops for managers and workers about adjusting to night and shift work and improving workplace conditions.

45. Prepare and distribute easy-to-understand leaflets for workers about risks due to night and shift work and necessary countermeasures.

46. Promote means of transferring work skills and techniques for planning and implementing night work tasks to younger workers.

47. Provide opportunities of acquiring and upgrading working skills and expertise

48. Make publicity efforts for making known the advantages of shiftworking jobs.

[ ] No [ ] Yes [ ] Priority

[ ] No [ ] Yes [ ] Priority

[ ] No [ ] Yes [ ] Priority

[ ] No [ ] Yes [ ] Priority
[ ] No [ ] Yes [ ] Priority 


\section{REFEREN CES}

1. Costa G. The impact of shift and night work on health. App Ergon 1996;27:9-16.

2. Harma MI, IImarinen JE. Towards the 24-hour society - new approaches for aging shift workers? Scand J Work Environ Health 1999;25:610-5.

3. Kawakami T, Kogi K. Action-oriented support for occupational safety and health programs in some developing countries in Asia. Int J Occup Saf Ergon 2001;7:421-34.

4. Kawakami T, Kogi K. Trends in occupational safety and health management systems in Asia and thre acific. Asian Pac Newsl Occup Health Saf 2002;9:42-7.

5. Knauth P. Innovative worktime arrangements. Scand J Work Environ Health 1998;24 Suppl 3:13-17.

6. Knauth P. Strategies for the implementation of new shift systems. J Hum Ergol (Tokyo) 2001;30:9-14.

7. Kogi K. Job content and working time: the scope for joint change. Ergonomics 1991;34:757-73.

8. Kogi K. Increasing flexibility in shiftwork arrangements. Work Stress 1995;9:211-218.

9. Kogi K. Implications of flexible work systems for work studies. J Hum Ergol (Tokyo) 1997;26:89-97.

10. Kogi K. International regulations on the organization of shift work. Scand J Work Environ Health 1998;24 Suppl 3:7-12.
11. Kogi K. Ergonomic guidelines for managers and workers in shiftworking plants: experiences from power plant maintenance work. In: Marek T, O ginska H, Pokorski J, Costa G, Folkard S, editors. Shiftwork 2000. Krakow: Institute of Management, Jagiellonian Univertsity; 2000. p. 173-86.

12. Kogi K. Healthy shiftwork, healthy shiftworkers. J Hum Ergol (Tokyo) 2001;30:3-8.

13. Kogi K. Work improvement and occupational safety and health management systems: common features and research needs. Ind Health 2002;40:121-33.

14. Kogi K, DiMartino VG. Trends in the participatory process of changing shiftwork arrangements. Work Stress 1995;9:298-304.

15. Monk TH, Folkard S, Wedderburn A. Maintaining safety and high performance on shiftwork. Appl Ergon $1996 ; 27: 17-23$

16. Morray N. Culture, politics and ergonomics Ergonomics 2000;43:858-68.

17. Rutenfranz J. Occupational health measures for nightand shiftworkers. J Hum Ergol (Tokyo) 1982;11 Suppl:67-86.

18. Sakai K. The current situation of shiftwork systems and the improvement of these systems. I Sci Labour 2000;76:417-40.

19. Wedderburn A, editor. Guidelines for siftworkers. Dublin: European Foundation for the Improvement of Living and Working; 1991. 